\title{
PENGAJIAN TAFSIR $A L$-IBRĪ $Z$ OLEH KIAI AHMAD MUSTOFA BISRI DI PONDOK PESANTREN RAUDLATUT THALIBIN REMBANG DALAM PERSPEKTIF FENOMENOLOGI AGAMA
}

\author{
Mudawamah \\ STAI Al-Anwar Sarang \\ m.wamah@yahoo.com \\ Muhamad Asif \\ Dewan Riset Daerah Kabupaten Rembang \\ asifelfarizi@gmail.com
}

\begin{abstract}
The study of al-Ibrīz's interpretation at Pesantren Raudlatut Thalibin Rembang is attended by various groups of people, both from parents and young people, employees, farmers, traders and retirees. The various backgrounds of the congregation there, in terms of age and profession, make different beliefs or awareness of the congregation regarding the recitation of al-Ibrīz and their way of internalizing the religious values contained in the recitation. By using qualitative methods and a phenomenological approach to religion, this study seeks to portray a picture of the culture and awareness of the recitation community towards the study of al-Ibrīz interpretation at pesantren Raudlatut Thalibin, Rembang. The research shows that the participants believe that the recitation of al-Ibrīz interpretation is a field of blessing, a way to get closer to Allah Subhānahu wa Ta'ālā, connect silaturrahmi, add insight, fill spare time, seek fortune and expect the efficacy of al-Ibrīz's tafsir closing prayer for their goals to be come true. Meanwhile, the way the congregation internalizes the religious values contained in the recitation of al-Ibriz's interpretation through four stages, namely listening carefully, reviewing it, applying it within oneself, and make it habit in daily life.
\end{abstract}

Key Word: Phenomenology of Religion,, Community Awareness, Living Qur'an, Study of Tafsir al-Ibrīz

\begin{abstract}
Abstrak
Pengajian tafsir al-Ibrīz di Pondok Pesantren Raudlatut Thalibin Rembang dihadiri oleh berbagai macam kalangan masyarakat, baik dari orang tua maupun anak muda, pengawai, petani, pedagang serta pensiunan. Bermacammacamnya latar belakang jamaah yang hadir baik dari segi usia maupun profesi menjadikan berbedanya keyakinan atau kesadaran jamaah terhadap pengajian tafsir al-Ibrizz serta cara mereka dalam menginternalisasi nilai-nilai agama yang terkadung dalam pengajian tersebut. Dengan menggunakan metode kualitatif dan pendekatan fenomenologi agama, penelitian ini berupaya memotret gambaran budaya dan kesadaran komunitas pengajian terhadap Pengajian tafsir al-Ibrīz di Pondok Pesantren Raudlatut Thalibin Rembang. Penelitian menunjukkan bahwa pengajian tafsir al-Ibrīzdiyakini oleh pesertanya sebagai ladang berkah, salah satu cara mendekatkan diri kepada Allah Subhānahu wa Ta'ālā, menyambung tali silaturrahmi, menambah wawasan, mengisi waktu luang, mencari rizki serta mengharapkan dari
\end{abstract}


doakhataman tafsir al-Ibrizz agar mendapatkan hajat-hajat yang diinginkan. Sedangkan cara jamaah menginternalisasi nilai-nilai agama yang terkandung dalam pengajian tafsir al-Ibrīzmelalui empat tahap, yaitu mendengarkan dengan seksama, mengkaji ulang, menerapkan dalam diri sendiri, dan pembiasaan dalam kehidupan sehari-hari.

Kata Kunci:Fenomenologi Agama,Kesadaran Masyarakat, Living Qur'an, Pengajian Tafsir al-Ibrīz.

\section{A. Pendahuluan}

Ranah penelitian al-Quran terbagi menjadi dua kategori, yaitu kajian internal al-Quran dan kajian eksternal al-Quran. ${ }^{1}$ Kajian internal al-Quran berupaya mengungkap aspek makna dan pesan yang terkandung dalam al-Quran (kajian tafsir). Sedangkan kajian eksternal alQuran berupaya mengungkap sejarah teks al-Quran, konteks sosio-historis al-Qur'an, aspek asbābun nuzūl, sejarah kodifikasi al-Quran. Seiring perkembangan zaman, kajian al-Quran merambah pada kajian tentang respon dan resepsi masyarakat terhadap kehadiran al-Quran itu sendiri, yang biasa disebut dengan istilah living quran.

Living quran merupakan model studi yang menjadikan fenomena yang hidup ditengah masyarakat Muslim terkait dengan al-Quran. Livingquran bermula dari fenomena Qur'an in Everyday Life, yakni makna dan fungsi al-Quran yang riil dipahami dan dialami masyarakat Muslim $^{2}$. Dengan kata lain, living quran merupakan penelitian ilmiah tentang berbagai peristiwa sosial terkait dengan keberadaan al-Quran ditengah masyarakat. Salah satu contoh kajian living quran adalah pengajian tafsir al-Quran di Pondok Pesantren Raudlatut Thalibin Rembang.

Pengajian tafsir al-Quran di Pondok Pesantren Raudlatut Thalibin Rembangmengkaji Tafsir Al-Ibrīz karya KH. Bisri Mustofa hingga saat ini. Pengajian ini diikuti oleh berbagai macam masyarakat dengan berbagai usia dan kalangan.Hal ini tentumenimbulkan perbedaan pandangan dan keyakinan tentang bagaimana pengajian tafsir al-Ibrīz tersebut. Namun juga menimbulkan perbedaan dalam menginternalisasikan nilai-nilai yang diajarkan saat pengajian tafsir al-Ibrīz oleh KH. Ahmad Mustofa Bisri.

\footnotetext{
${ }^{1}$ Abdul Mustaqim, Metode Penelitian al-Quran dan Tafsir(Yogyakarta: Idea Press, 2015), hlm. 26.

${ }^{2}$ M. Mansur, Living Qur'an dalam Lintasan Sejarah Studi Qur'an, dalam Metodologi Penelitian Living Qur'an dan Hadis, Ed. Sahiron Syamsuddin (Yogyakarta: TH Press, 2007), hlm. 5.
} 
Pengajian Tafsir Al-Ibrīz Oleh Kiai Ahmad Mustofa Bisri .....

Mudawamah \& Muhamad Asif

Doi: doi.org/10.47454/itqan.v4i2.682

\section{B. Pendekatan Fenomenologi}

Istilah pendekatan disamakan dengan kerangka teori dan didefinisikan berupa seperangkat konsep yang berhubungan satu dengan yang lain secara logis membentuk sebuah kerangka pemikiran yang berfungsi untuk memahami, menafsirkan, dan menjelaskan kenyataan atau masalah yang dihadapi. ${ }^{3}$ Fenomenologi berupaya mengungkapkan dan memahami realitas penelitian berdasarkan perspektif subjek penelitian. Hal ini menuntut bersatunya subyek peneliti dengan subyek pendukung obyek penelitian. Keterlibatan subyek peneliti di lapangan dalam menghayatinya menjadi salah satu ciri utama penelitian dengan pendekatan fenomenologi. Fenomenologi yang digunakan dalam perspektif Alfred Schutz lebih menekankan pada pentingnya intersubjektivitas. Inti dari fenomenologi Schutz adalah memandang bahwa pemahaman atas tindakan, ucapan, dan interaksi merupakan prasyarat bagi eksistensi sosial apapun. ${ }^{4} \mathrm{Hal}$ ini menjelaskan bahwa fenomenologi mengkaji bagaimana anggota masyarakat menggambarkan dunia sehari-harinya, terutama bagaimana individu dengan kesadarannya membangun makna dari hasil interaksi dengan individu lainnya.

Penelitian fenomenologi pada hakekatnya adalah berhubungan dengan interpretasi terhadap realitas. Fenomenologi mencari jawaban tentang makna dari suatu fenomena. Pada dasarnya, ada dua hal utama yang menjadi fokus dalam penelitian fenomenologi yakni:

1. Textural description: sesuatu yang dialami oleh subjek penelitian tentang sebuah fenomena. Hal yang dialami merupakan aspek objektif, data yang yang bersifat faktual, hal yang terjadi secara empiris.

2. Structural description: bagaimana subjek mengalami dan memaknai pengalamannya. Deskripsi ini berisi aspek subjektif. Aspek ini menyangkut pendapat, penilaian, perasaan, harapan, serta respons subjektif lainnya dari subjek penelitian berkaitan dengan pengalamannya itu. ${ }^{5}$

\footnotetext{
${ }^{3}$ Heddy Sri Ahimsa, "Fenomenologi Agama: Pendekatan Fenomenologi untuk Memahami Agama",Jurnal Walisongo,vol. 20, no. 2(2012), hlm. 272.

${ }^{4}$ Deddy Mulyana, Metodologi penelitian Kualitatif, Paradigma Baru Ilmu Komunikasi dan Ilmu Sosial lainnya(Bandung: Remaja Rosdakarya, 2001), hlm. 62.

${ }^{5}$ O. Hasbiansyah, “Pendekatan Fenomenologi: Pengantar Praktik Penelitian dalam Ilmu Sosial dan Komunikasi”,MediatorJurnal Komunikasi, vol. 9, no. 1 (2008), hlm.171.
} 


\section{Sekilas tentang Pengajian Tafsir Al-Ibrīz dan Pondok Pesantren Raudlatut Thalibin}

\section{Gambaran Umum Pengajian Tafsir Al-Ibriz}

Setiap seminggu sekali, pada hari Jumat kegiatan pengajian tafsir al-Ibrīz berlangsung. Kegiatan pegajian tafsir al-Ibrīz berlangsung tidak kurang lebih dari satu jam, yaitu pada pukul 08.30 pagi sampai pukul 09.30 pagi. Sebelum acara dimulai, para jamaah sudah berdatangan memadati area pengajian tafsir al-Ibrīz yaitu di Pondok Pesantren Raudlatut Thalibin Leteh Rembang Jawa Timur. Antara jamaah putra dan putri dibatasi dengan sekat. terkadang banyak jamaah putri yang dengan sengaja memilih duduk diluar aula atau teras kediaman Gus Mus agar dapat melihat secara langsung Gus Mus pada saat keluar dari kediaman dan akan menuju ke aula utama pondok.

Tempat yang digunakan para jamaah ketika mengaji tafsir al-Ibrīz sekarang yaitu untuk jamaah putra di dalam sebagian aula utama pondok, aula tengah pondok putra dan sekitarnya, ada yang berada dijalanan pondok putra, di sekitar kantin pondok putra atau area pondok putra. Sedangkan jamaah putri sebagian berada di aula utama Pondok Pesantren Raudlatut Thalibin, di teras, di ndalem Gus Mus dan depannya, di depan ndalem Gus Adib, didepan pondok Putri Raudlatut Thalibin. Para jamaah putri yang berada diluar disediakan tikar dari pengurus pengajian tafsir al-Ibrīz.

Di pengajian tafsir al-Ibrīz ini, ada tradisi yang terlihat ketika para jamaah baru datang dan ketika selesai pengajian yaitu tradisi saling bersalam-salaman atau berjabat tangan. Setiap jamaah yang baru datang, akan menyalami jamaah yang sudah ada disana dan disekitarnya yang bisa dijangkau untuk bersalaman. Tradisi ini juga dilakukan ketika pengajian tafsir alIbrīz selesai ketika para jamaah membubarkan diri sembari bersalam-salaman atau berjabat tangan dengan para jamaah lainnya.

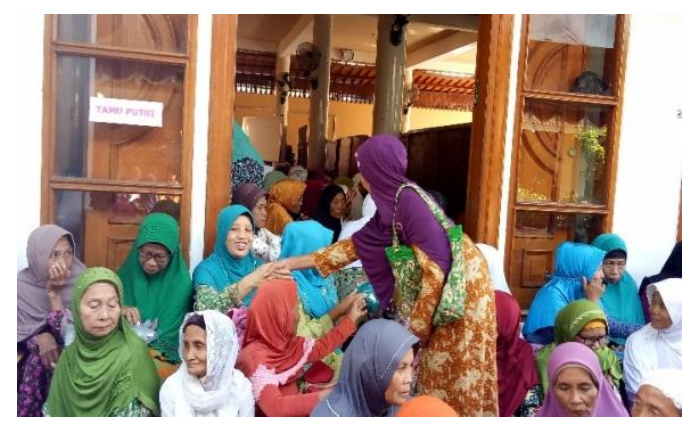

Gambar 1:

Peserta pengajian tafsir al-Ibrīz yang baru datang saling bersalaman dengan jamaah yang sudah ada disana (04 Mei 2018) 
Pengajian Tafsir Al-Ibrīz Oleh Kiai Ahmad Mustofa Bisri ..... Mudawamah \& Muhamad Asif

Doi: doi.org/10.47454/itqan.v4i2.682

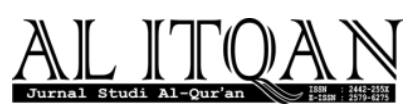

Gus Mus akan keluar dari kediamannya kurang lebih pada pukul 08.30 untuk memulai pengajian tafsir al-Ibrīz. Ketika keluar dari kediamannya para jamaah berebut untuk bisa berjabat tangan dengan Gus Mus. Jika ada jamaah yang membawa anak kecil dan ikut berjabat tangan dengan Gus Mus pasti anak kecil tersebut akan menerima hadiah dari Gus Mus yaitu berupa selembaran uang. Gus Mus berjabat tangan dengan semua jamaah baik putra maupun putri yang berada disepanjang jalan menuju aula utama pondok.

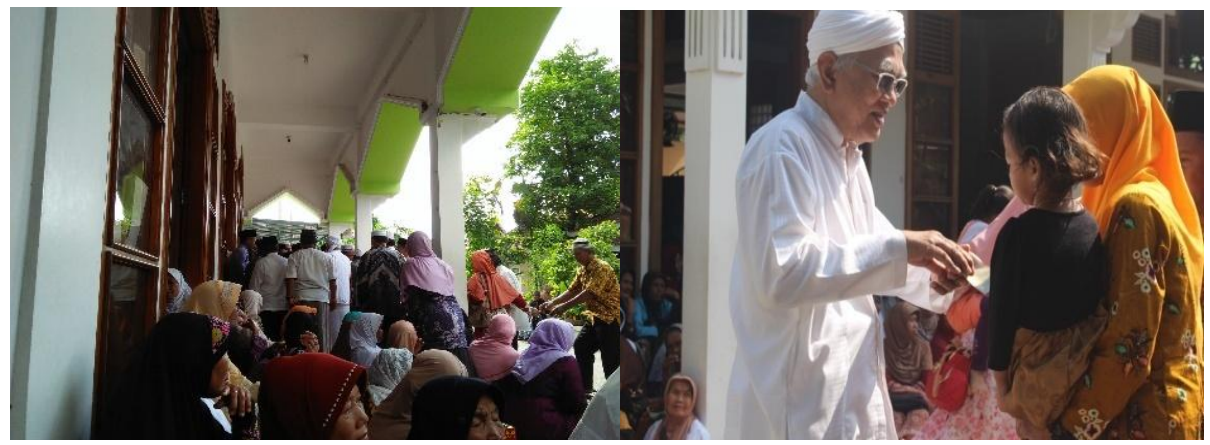

Gambar 2:

Para jamaah sedang berebut untuk berjabat tangan dengan Gus Mus ketika

Gus Mus akan memasuki aula utama pondok (06 April 2018)
Gambar 3:

Gus Mus sedang memberikan hadiah (uang selmbaran) kepada anak kecil setelah berjabat tangan (06 April 2018)

Gus Mus masuk ke dalam aula dan duduk di tempat biasa yang digunakan untuk menerangkan tafsir al-Ibriz, yaitu tepat dipaling depan dan menghadap ke barat dan berhadapan dengan para jamaah putra yang mana diatas tempat Gus Mus ada foto dari ayahnya yaitu Mbah Bisri Mustofa dan kakaknya yaitu Kholil Bisri. Ditempatnya tersebut tersedia kursi yang tidak tinggi dan meja yang diatasnya ada mikrofon dan tidak ketinggalan juga tafsir al-Ibrìz. Jarak dengan para jamaah putra dengan Gus Mus tidaklah jauh hanya berjarak kurang lebih setengah meter saja. Jamaah putra duduk berada disekitar Gus Mus, disamping kanan kiri serta depan persis Gus Mus.

Pengajian tafsir al-Ibrīz diawali dengan ucapan salam dari Gus Mus, dan para jamaah menjawab salam dengan antusias kemudian mereka hening. Setelah itu Gus Mus memulainya dengan bacaan basmalah dan al-fatihah. Kemudian Gus Mus membacakan ayat-ayat al-Quran yang akan dijelaskan pada saat itu. Di sela-sela setiap Gus Mus berhenti membaca satu ayat, para jamaah dengan kompak menjawab dengan kata "Allah". Setelah membacakan semua ayat yang akan dijelaskan, kemudian Gus Mus menjelaskan setiap ayat terkadang setiap per kata dari satu ayat al-Quran. Gus Mus menjelaskan dengan menggunakan bahasa jawa ngoko yaitu bahasa jawa yang sudah biasa digunakan oleh masyarakat Rembang. Namun Gus Mus 
juga tetap menggunakan bahasa indonesia sehingga diharapkan semua jamaah mengerti apa yang dijelaskan.

Para jamaah yang membawa kitab tafsir al-Ibrīz khusyuk mendengarkan, menyimak serta menulis keterangan-keterangan yang disampaikan oleh Gus Mus yang dirasa perlu untuk dicatat. Sedangkan, yang tidak membawa kitab terkadang juga ada yang ikut melihat kitab yang yang dibawa peserta disampingnya, dan dengan khusyuk juga mendengarkan keterangan dari Gus Mus. Ketika Gus Mus menjelaskan dengan gurauan atau candaan para jamaah tidak segan-segan juga ikut tertawa.

Kegiatan pengajian tafsir al-Ibrizz di Pondok Pesantren Raudlatut Thalibin yang berlangsung setiap hari jumat dan tidak pernah libur kecuali pada bulan ramadhan. Sehingga Gus Mus mempunyai seseorang yang biasa mewakili atau menggantikan posisinya ketika sedang berhalangan hadir. Penganti tersebut adalah Kiai Syarofuddin yang merupakan santri Raudlatut Thalibinyang sudah ada sejak Mbah bisri Mustofa masih hidup. Model penyampaian Kiai Syarofuddin tidak jauh berbeda dengan Gus Mus.

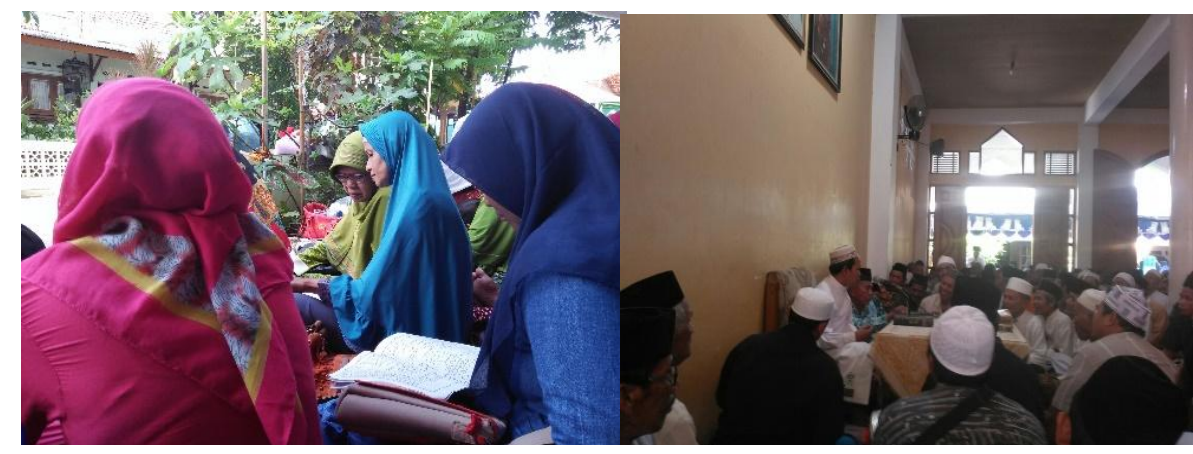

Gambar 4:

Jamaah putri yang diluar aula sedang khusyuk menyimak dan mendengarkan penjelasan tafsir al-Ibrīz oleh Gus Mus (27 April 2018)
Gambar 5:

Jamaah putra dengan khusyuk mendengarkan dan memperhatikan penjelasan dari Kiai Syarofuddin ketika menggantikan Gus Mus yang sedang berhalangan (04 Mei 2018).

Kegiatan pengajian tafsir al-Ibrīz selesai tidak kurang dan tidak lebih dari satu jam yaitu biasanya berakhir pada pukul 09.30 pagi. Pengajian diakhiri dengan bacaan wa allah 'alam bișsawāb, hamdalah dan al-fatihah. Kemudian para jamaah putra berebut untuk bersalaman dengan Gus Mus dan selama perjalanan menuju ke ndalem ${ }^{6}$ nya, Gus Mus juga bersalaman dengan jamaah yang mendekat dengannya, terkadang ada juga yang meminta foto bareng.

\footnotetext{
${ }^{6}$ rumah
} 


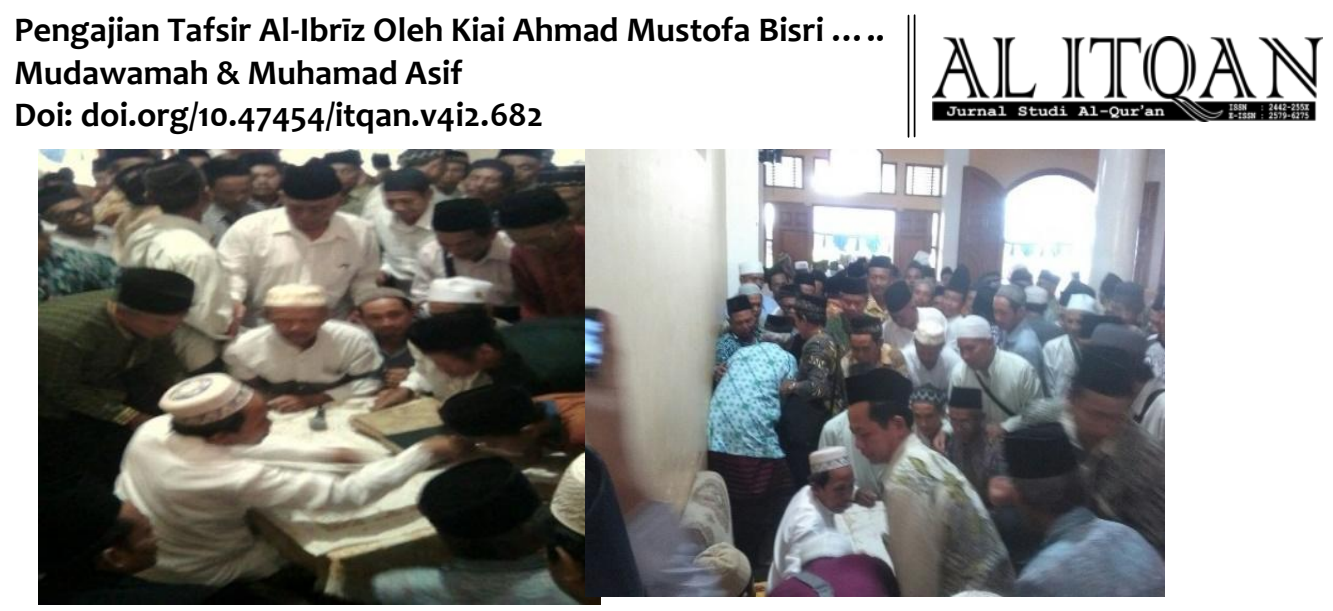

Gambar 6 dan Gambar 7:

Suasana ketika para jamaah putra sedang berebut untuk bisa bersalaman dengan Kiai Syarofuddin saat selesai mengaji tafsir al-Ibrīz (04 Mei 2018)

Tradisi dari pengajian tafsir al-Ibrīz yang berlangsung setiap sebulan sekali, yaitu pada hari jumat wage $^{7}$, yakni ada acara makan-makan setelah pengajian berlangsung. Tidak hanya para jamaah yang ikut, tetapi para pedagang dan tukang becak yang berada di area pengajian juga mendapatkan makanan. Jamaah pada Jum'at wage lebih banyak, diperkirakan bahwa jamaah yang hadir kira-kira mencapai 1000 orang. Hal ini dapat dilihat dari penyediaan piringan yang telah disediakan oleh pihak ndalem Gus Mus yaitu 1000 piring. ${ }^{8}$

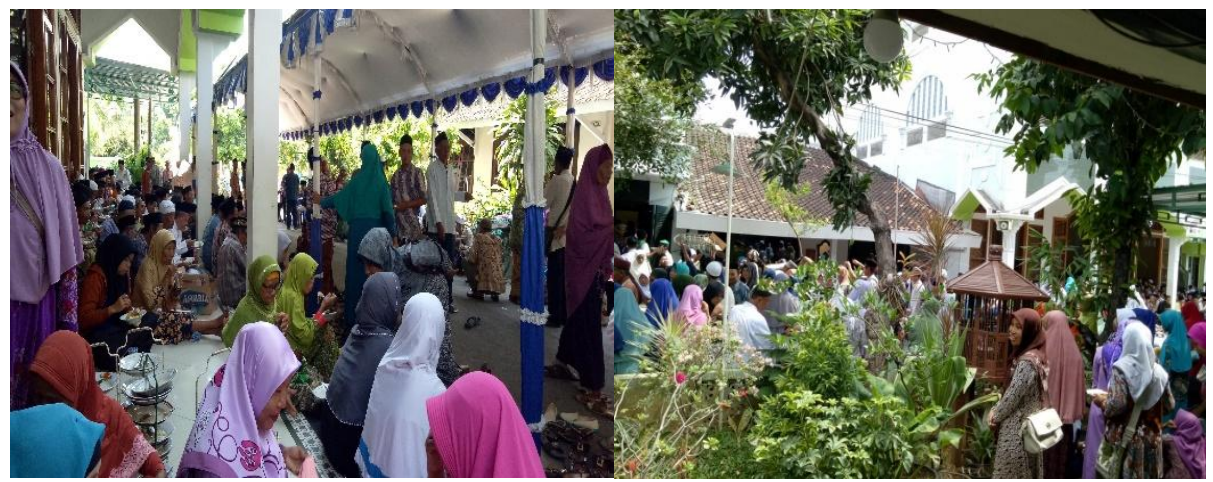

Gambar 8:

Para jamaah sedang makan setelah pengajian tafsir al-Ibrīz pada saat jumat wage yang merupakan peringatan hari kelahiran Gus Mus (04 Mei 2018)
Gambar 9:

Jumlah peserta pengajian tafsir al-Ibriz yang datang ketika hari jumat wage lebih banyak dari pada hari jumat biasanya (04 Mei 2018)

Tradisi yang lain dari pengajian tafsir al-Ibrīz di Pondok Pesantren Raudlatut Thalibin yaitu para jamaah sowan kepada kiai-kiai yang ada di Pondok Pesantren Raudlatut Thalibin setelah pengajian usai. Setelah pengajian selesai dan Gus Mus masuk ke ndalemnya, ada sebagian para jamaah yang sowan ke Gus Mus. Ada sebagian juga yang sowan ke ndalem Kiai Syaroffudin.

\footnotetext{
${ }^{7}$ Salah satu nama weton dalam hari yang ada di dalam Bahasa Jawa.

${ }^{8}$ Wawancara dengan Almas, Rembang, 09 September, 2018.
} 


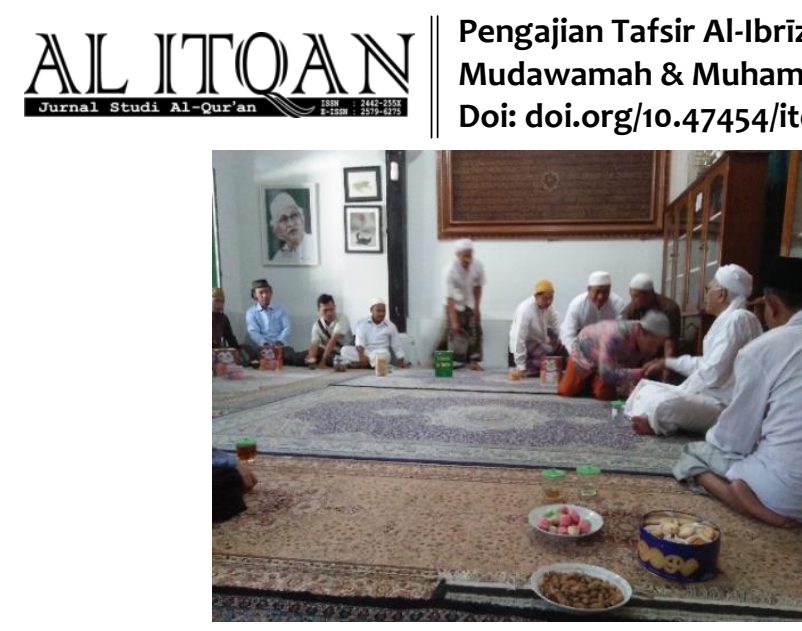

Gambar 10:

Suasana saat para jamaah sedang sowan ke Gus Mus setelah selesai pengajian tafsir al-Ibrīz(06 April 2018).

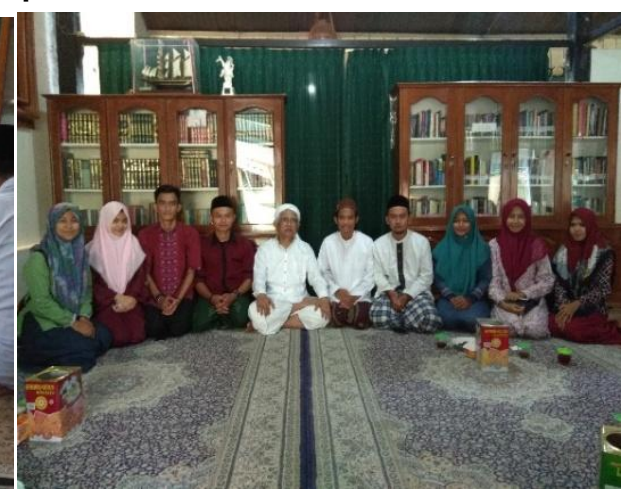

Gambar 11:

Salah satu rombangan dari UIN Syarif Hidayatullah Jakarta yang sengaja sowan pada hari jumat untuk mengundang Gus Mus untuk mengisi acara seminar. (27 April 2018)

\section{Sejarah Pengajian Tafsir al-Ibrīz}

Pengajian Tafsir al-Ibrīz yang dipimpin oleh Ahmad Mustofa Bisri merupakan pengajian rutin yang dilaksanakan setiap hari jumat dan bertempat di Pondok Pesantren Raudlatut ThalibinRembang. Pengajian tafsir ini mulanyadiampu oleh KH. Bisri Mustofa, ayah dari KH. Ahmad Mustofa Bisri. KH.Bisri Mustofa adalah pengarang asli tafsir al-Ibrizz tersebut.Dikalangan masyarakat, pengajian ini dikenal dengan sebutan pengajian selasa jumat. ${ }^{9} \mathrm{Hal}$ ini, karena pengajian diadakan pada hari selasa dan jumat. Kitab yang dikaji pada hari Selasa adalah kitab irsyad al-ibād sedangkan pada hari Jumat mengkaji tafsir al-Quran yaitu tafsir al-Ibrīz. ${ }^{10}$

Sejarah Awal mulanya pengajian tafsir al-Ibrīz ini, dilandasi dari keinginan KH Bisri Mustofa dalam meneruskan tradisi pengajian gurunya sekaligus ayah mertuanya, yaitu $\mathrm{KH}$ Cholil Kasingan. ${ }^{11}$ Namun Pengajian ini memiliki perbedaan, yaitu pada waktu serta kajian yang dikajinya. Dahulu KH. Cholil mengadakan pengajian bersama warga seminggu sekali, yaitu malam senin.Dalam kesamaannya, pengajian jum'at Kiai Bisri dengan pengajian malam senin, adalah sama-sama diperuntukkan untuk kalangan umum yaitu bukan hanya santri pondok saja.Masyarakat ini bisa dari kalangan orang-orang desa dan para warga setempat yang menginginkan mengaji dan ngalap berkah ${ }^{12}$ kepada Kiai Bisri Mustofa. ${ }^{13}$

\footnotetext{
${ }^{9}$ Wawancara dengan Suyoto Zuhdi, Rembang,13 April, 2018.

${ }^{10}$ Mustofa Bisri, "Dialog dalam Acara Penerimaan Peserta PKL", Rembang, 28 September, 2017.

${ }^{11}$ Wawancara dengan Adib Bisri Hattani, Rembang, 29September, 2017.

${ }^{12}$ Mengharap berkah.
} 
Pengajian Tafsir Al-Ibrīz Oleh Kiai Ahmad Mustofa Bisri .....

Mudawamah \& Muhamad Asif

Doi: doi.org/10.47454/itqan.v4i2.682

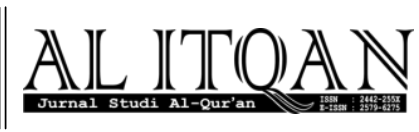

Pengajian Tafsìr al-Ibrīz sendiri sebenarnya sudah mulai dilaksanakan ketika KH. Bisri Mustofa masih hidup. KH. Syarofuddin mengatakan bahwa terkait dengan tahun berapa KH. Bisri Mustofa memulai mengaji kitab Tafsìr al-Ibrizz belum diketahui secara pasti. Akan tetapi, pengajian kitab al-Ibrīz untuk masyarakat umum dimulai setelah KH. Bisri Mustofa selesai mengarang kitab al-Ibrīz tersebut. ${ }^{14}$

Menurut penjelasan KH. Syarofuddin, yaitu salah satu santri KH. Cholil Bisri, putra pertama dari KH. Bisri Mustofa, Tafsīr al-Ibrīz adalah sebuah tafsir al-Qur`an yang mudah dipahami oleh orang-orang awam. Pemilihan bahasa Jawa yang terdapat dalam kitab tafsir itulah yang membuat masyarakat umum tertarik untuk memahami isi yang terkandung di dalamnya. Selain itu, KH. Syarofuddin juga mengatakan bahwa Tafsìr al-Ibrīz merupakan "Tafsir hidup", yaitu tafsir bahasa Jawa yang dapat dipahami apabila si pembaca dapat menyesuaikan intonasi dan pola bahasa bacaan yang tertuang di dalamnya. Sepeninggal KH. Bisri Mustofa, 1977, pengajian tafsir kitab Tafsīr al-Ibrīz hari Jumat bersama warga digantikan oleh putra beliau, yaitu KH. Mustofa Bisri. Apabila KH. Mustofa Bisri sedang ada halangan, pengajian digantikan oleh KH. Syarofuddin.

Pengajian kitab Tafsīr al-Ibrīz ini terus mengalami perkembangan jumlah audien sampai sekarang. Menurut pengakuan dari beberapa anggota jamaah pengajian Tafsīr al-Ibrīz yang telah mengikuti pengajian dari tahun 2011, jumlah jamaah yang mengikuti pengajian selalu bertambah dari tahun ke tahun. Hal tersebut dapat dilihat dari data sementara anggota yang membuat kartu anggota jamaah selasa jumat yaitu kurang lebih 1900an lebih. Bapak Suyoto Zuhdi selaku sekretaris pengurus ngaji selasa jumat mengungkapkan bahwa jamaah pengajian ini semakin meningkat. Hal ini dilihat dari kartu anggota yang bertambah tiap $\operatorname{tahun}^{15}$

\section{Tujuan dan Sistem Pengajian al-Ibrīzo}

Pertama kali pengajian Tafsīr al-Ibrīz diampu oleh KH. Bisri Mustofa di kelurahan Leteh kecamatan Rembang kabupaten Rembang. Dalam segi pengetahuan ilmu agama, pada saat itu masyarakat setempat masih tergolong awam sehingga pengajian Tafsīr al-Ibrīz yang diadakan oleh KH. Bisri Mustofa sedikit sekali peminatnya. Dan pengajian hanya dilakukan di mushola beliau saja karena masih sedikit sekali yang minat dalam pengajian tersebut. Pada

\footnotetext{
${ }^{13}$ Ahmad Bisri Dzalieq, "KH. Bisri Mustofa dan Perjuangannya”.Skripsi(Yogyakarta: UIN Sunan Kalijaga, 2008), hlm. 67.

${ }^{14}$ Wawancara dengan Syarofuddin, Rembang, 29 September, 2017.

${ }^{15}$ Wawancara dengan Suyoto Zuhdi, Rembang, 13 April, 2018.
} 
awal permulaan pengajian tersebut hanya diikuti sekitar 9 orang saja. Itupun harus ditegur, dan dijemput di rumah untuk diajak ke pengajian. Dalam pengajian Tafsìr al-Ibrīz ini mempunyai tujuan umum yaitu menyebarkan ajaran ilmu agama Islam kepada masyarakat yang tergolong masih awam dalam ilmu tersebut. Setiap orang Islam mempunyai kewajiban dalam mencari ilmu dari buaian ibu sampai ke liang lahat seperti yang dikatakan dalam hadis Nabi.

Dalam menyampaikan pengajian kitab Tafsīr al-Ibrīz, terkadang KH. Mustofa Bisri juga menggunakan bahasa kiasan dan perumpamaan, misalnya ada bahasa yang tidak dapat dipahami maka KH. Bisri Mustofa atau Gus Mus menggunakan bahasa-bahasa yang disesuaikan dengan perkembangan zamannya. Sistem pengajian yang dipakai oleh keduanya berdua sama, yaitu menggunakan metode ngaos bandongan ${ }^{16}$.

Perkembangan dalam pengajian Tafsìr al-Ibrīz mempunyai ciri khas tersendiri yang membuat banyak orang tertarik dan antusias menghadiri pengajian al-Ibrīz. Berikut ciri khas dari pengajian Gus Mus yang juga tidak jauh berbeda dengan pengajian KH. Bisri Mustofa ${ }^{17}$ :

- Penjelasannya menyesuaikan dengan kondisi pendengar yakni menggunakan bahasa yang mudah dipahami oleh pendengar, untuk menghindari faktor-faktor yang dapat menghantar pada kesalah pahaman. Gus Mus maupun ayahnya tidak membedakan penafsiran teksnya dalam bentuk makna pegonnya saja, tapi di deskripsikan dengan bentuk ilustrasi seperti keadaan atau kejadian yang terjadi sekarang-sekarang ini.

- Mengawali pengajian tafsir dengan lafal basmalah, hamdalah, atau dengan membaca al-Fätihah

- Menggunakan bahasa

- Mengaji juga diimbangi dengan bersenda gurausehingga membuat para pendengar tertawa dan tidak bosan untuk mengikuti pengajian.

- Mengaitkan dengan cerita Nabiagar dapat diambil hikmahnya dan dapat diteladani oleh umat Islam zaman sekarang.

Di samping itu, beberapa hal unik juga dapat dijumpai dalam pengajian Tafsìr al-Ibrīz, seperti pola penghormatan Gus Mus kepada para jamaahnya yakni dengan menjamunya.

\footnotetext{
${ }^{16}$ Metode pengajaran yang semua santri berkumpul dan mengaji bersama dengan cara mendengarkan pengajaran dari guru. Sedangkan sang guru membacakan dan menjelaskan kitab yang diajarkan. Dalam Zamakhsyari Dhofir, Tradisi Pesantren Studi Pandangan Hidup Kyai dan Visinya Mengenai Masa Depan Indonesia (Jakarta: LP3ES, 2011), hlm. 54.

${ }^{17}$ Wawancara dengan Syarofuddin, Rembang, 29 September, 2017.
} 
Pengajian Tafsir Al-Ibrīz Oleh Kiai Ahmad Mustofa Bisri .....

Mudawamah \& Muhamad Asif

Doi: doi.org/10.47454/itqan.v4i2.682

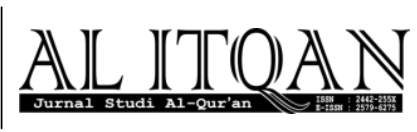

Mbah Khomariyah yang merupakan salah satu peserta jamaah pengajian tafsir al Ibrīzmengungkapkan bahwa setiap hari jumat wage para jamaah, tukang becak, pedagang, yang ada disini setelah pengajian itu diberi makanan oleh Gus Mus. ${ }^{18}$

\section{Sekilas Tentang Tafsir al-Ibrīz}

Kitab al-Ibrīz merupakan kitab tafsir karangan KH. Bisri Mustofa yang lahir pada tanggal 1915 M dan wafat pada tahun 1977 M. Kitab al-Ibrīz ini lengkap tiga puluh juz dan ditafsirkan kedalam Bahasa Jawapegon, saat ini sudah ada cetakan yang mengunakan Bahasa Jawa latin. Nama al-Ibrīzseperti yang diutarakan Gus Mus, berasal dari kalimat al-Qur'an al'Aż̀z. Dari kata al-'Azīz itu maka menjadi Al-Ibrīz, karena orang dahulu itu suka menyajakkan kata. $^{19}$

Penulisan awal Tafsir al-Ibrīz dilakukan oleh dua santri senior KH. Bisri Mustofa, keduanya menulis keterangan ayat-ayat al-Quran yang disampaikan oleh KH. Bisri Mustofa pada saat pengajian Tafsir. Setelah pengajian al-Quran tersebut khatam kedua santrinya sowan membawa hasil catatannya kepada KH. Bisri Mustofa, mengoreksi dan menggabungkan penulisan Tafsir al-Quran. Oleh karena itu, jadilah satu karya tulisan tafsir al-Quran yang diberi nama Tafsir $a l-I b r \overline{\imath z} .{ }^{20}$ Kitab ini ditulis oleh KH. Bisri Mustofa ketika Kiai Bisri menginjak usia 40 tahun. Penulisan Tafsir al-Ibrīz membutuhkan waktu kurang lebih 10 tahun dan selesai tiga puluh juz pada tahun 1950-an. ${ }^{21}$

Cetakan kitab Tafsir al-Ibrīz ini awalnya terdapat kesalahan penulisan dalam Surat alFath. Pada kitab Tafsir al-Ibrīz ditulis قد رضي اله على المؤمنين dan yang benar dalam al-Qur'an yaitu عن المؤمنين لقد رضي اله . Beberapa ulama yang mentashih kitab Tafsir al-Ibrīz yaitu al'Allamah al-Hafidz, KH. Arwani Amin, KH. Abu Umar, al- Mukarram al- Hafidz, KH. Hisyam dan juga Gus Mus ${ }^{22}$.

Adapun sistematika penulisanal-Ibrīz memiliki tiga bagian yakni: Bagian tengah berisi ayat al-Quran yang ditulis dengan disetai maknanya dalam bentuk Arab Jawa (pegon); Bagian samping kanan, kiri dan bawah berisi penafsiran ayat; Keterangan-keterangan lain yang perlu

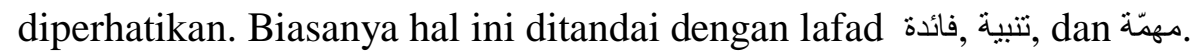

\footnotetext{
${ }^{18}$ Wawancara dengan Khomariyah, Rembang, 06 April, 2018.

${ }^{19}$ Disampaikan oleh Gus Mus dalam pembukaan praktik kuliah lapangan, di PP Roudlotut Tholibin Leteh, Rembang, 28 September, 2017.

${ }^{20}$ Wawancara dengan Ahmad Mustofa Bisri, Rembang, 29 September, 2017.

${ }^{21}$ Wawancara dengan Bisri Adib Hattani, Rembang, 29 September, 2017.

${ }^{22}$ Wawancara dengan Ahmad Mustofa Bisri, Rembang, 29 September, 2017.
} 


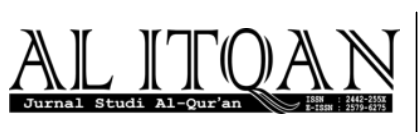

Pengajian Tafsir Al-Ibrīz Oleh Kiai Ahmad Mustofa Bisri ....

Mudawamah \& Muhamad Asif

Doi: doi.org/10.47454/itqan.v4i2.682

Ditinjau dari segi penjelasan penafsiran ayat, tafsir al-Ibrīz ditulis dan dipaparkan secara deskriptif (bayan). Ijtihad dari pemikiran Bisri Mustofa sendiri didapat dari pengolahan terhadap pendapat-pendapat mufasir terdahulu.

\section{Internalisasi Nilai-Nilai Agama Yang Terkandung Dalam Pengajian Tafsir Al-Ibrīz}

\section{Keyakinan Jamaah terhadap Pengajian Tafsir al-Ibrīz}

Keyakinan para jamaah Pengajian Tafsir al-Ibrīz terhadap Pengajian Tafsir al-Ibrīz KH. Mustofa Bisri di Podok Pesantren Raudlatut Thalibin Leteh terbagi menjadi beberapa keyakinan. Halini diperoleh dari wawancara para peserta jamaah yang dipilih secara acak oleh penulis. Adapun keyakinan yang diperoleh adalah sebagai berikut:

\section{a. Sebagai Ladang Berkah}

Berkah atau barokah yang biasa disebut oleh para jamaah tafsir al-Ibriz disini adalah menambahnya kebaikan dalam dirinya sendiri dalam kehidupannya. Hal ini, menjadi salah satu keyakinan para jamaah pengajian tafsir al-ibrīz. Mengikuti pengajian tafsir al-Ibrīz KH. Mustofa Bisri, menjadi ladang untuk mencari berkah dari pengajian tafsir itu sendiri dan dari KH. Mustofa Bisri. Dengan mengikuti pengajian tafsir al-Ibrīz mereka merasa selalu dekat dengan para alim ulama sehingga akan lebih mudah mendapatkan berkah dari Allah Subḥānahu wa Ta'ālā. Seperti yang diutarakan dari beberapa peserta pengajian tafsir al-Ibrīz KH Mustofa Bisri di Pondok Pesantren Raudlatut Thalibin Leteh sebagai berikut:

Bapak Adib mengungkapkan bahwa banyak orang yang yakin mereka akan mendapatkan berkah dari sang kyai. seperti yang awalnya tidak mengaji menjadi sering mengaji dan rezeki bertambah setelah mengikuti pengajian. ${ }^{23}$ Ibu Fariqoh yang merupakan salah satu peserta jamaah tafsir al-Ibrīz dari Pati yang juga berprofesi sebagai guru SD di tempat tinggalnya juga mengungkapkan bahwa ia ingin mendapatkan berkah dari pengajian tafsir tersebut dan kiai Mustofa Bisri. Ia juga selalu mengusahakan untuk selalu mengikuti pengajian meski terkadang tidak selalu hadir. ${ }^{24}$ Selain itu, Bapak Suyoto, salah satu pengurusjamaah pengajian ini juga mengemukakan hal serupa. Berkah yang ia dapat yakni bertambah rajin mengaji dan dapat memondokkan anak agar mengerti agama. ${ }^{25}$

\footnotetext{
${ }^{23}$ Wawancara dengan Adib, Rembang, 20 April, 2018.

${ }^{24}$ Wawancara dengan Fariqoh, Rembang, 06 April, 2018.

${ }^{25}$ Wawancara dengan Suyoto Zuhdi, Rembang, 29 April, 2018.
} 
Pengajian Tafsir Al-Ibrīz Oleh Kiai Ahmad Mustofa Bisri .....

Mudawamah \& Muhamad Asif

Doi: doi.org/10.47454/itqan.v4i2.682

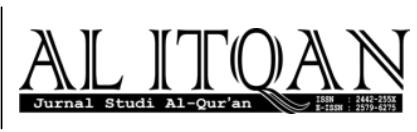

Dari pemaparan beberapa peserta pengajian tafsir al-Ibrizz diatas, sama dengan pemaparan yang diutarakan para peserta jamaah tafsir al-Ibrīz yang lainnya, diantaranya Bapak Nasir, Bapak Abdurrohman, Bapak Herman, Ibu Nunuk Linarsih, Ibu Zainab, yang meyakini bahwa Pengajian tafsir al-Ibrīz oleh KH Mustofa Bisri di Pondok Pesantren Raudlatut Thalibin membawa berkah bagi para peserta jamaah. Dengan sering menghadiri mengajian tafsir ini, mereka berkeyakinan hidup yang mereka jalani semakin bertambah baik dalam masalah ibadah duniawi maupun akhirat.

\section{b. Sebagai Sarana Untuk Lebih Dekat Kepada Allah Subhānahu Wa Ta’ālā}

Dari observasi yang penulis lakukan, dapat dilihat secara nyata bahwa kebanyakan para jamaah pengajian tafsir al-Ibrīz KH Mustofa Bisri adalah orang tua atau yang berusia diatas 50 keatas. Sehingga dari usia yang sudah berumur, para jamaah pengajian tafsir al-Ibrizz ini, mereka berkeyakinan bahwa pengajian tafsir al-Ibrīz merupakan sarana bagi mereka untuk lebih mendekatkan diri kepada Allah Subhāanahu wa Ta'ālā. Ibu Khodijah yang salah satu peserta pengajian tafsir al-Ibrīz yang lahir kira-kira tahun 1950an dan Mbah Sarman yang berumur lebih dari 100 tahun ${ }^{26}$ mengungkapkan bahwa dengan umurnya yang sudah tua dan ia tidak bisa mengaji, maka ia ingin mendekatkan diri kepada Allah dengan mengikuti pengajiannya Gus Mus. ${ }^{27}$ Begitupun dengan Ibu Mariatun yang sudah memasuki umur 75 tahun, mengungkapkan bahwa dampak positif mengikuti pengajian ini adalah menjadikannya terasa lebih khusyu' ketika beribadah sehingga ia merasakan lebih dekat dengan Allah. ${ }^{28} \mathrm{Ibu}$ Kasini yang berumur 80an juga mengungkapkan bahwa ketidaktahuannya dalam hal agama hanya sebatas engikuti pengajian agar lebih dekat dengan Allah. ${ }^{29}$

Selain dari keterangan Ibu Khadijah, ibu Mariatun, Mbah Sarman, Ibu Kasini diatas, terdapat juga persamaan keyakinan dari peserta jamaah pengajian tafsir al-Ibrīz yang lainnya, yaitu ibu Juwariyah yang merupakan pensiunan pegawai koperasi, ibu Murti yang berusia 73 tahun, Ibu Markamah yang berusia 61 tahun. Mereka semua menyakini bahwa diusia yang sudah tua, dengan mengikuti pengajian tafsir al-Ibrīz dapat menjadikan diri mereka lebih dekat dengan Allah Subhānahu wa Ta'ālā.

\footnotetext{
${ }^{26}$ Wawancara dengan Sarman, Rembang, 06 April, 2018.

${ }^{27}$ Wawancara dengan Khodijah, Rembang, 06 April, 2018.

${ }^{28}$ Wawancara dengan Mariatun, Rembang, 29 April, 2018.

${ }^{29}$ Wawancara dengan Kasini, Rembang, 29 April, 2018.
} 


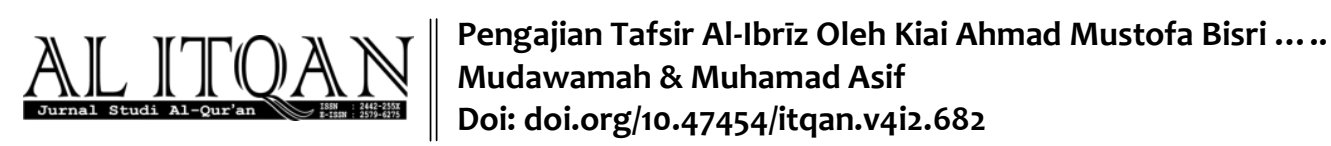

\section{c. Sebagai sarana menambah wawasan keilmuwan}

Istilah pengajian berasal dari kata kerja mengaji, yang berarti mempelajari ilmu agama melalui seseorang yang dianggap sebagai ahli agama atau kiai. ${ }^{\mathbf{3 0}}$ Dari pengertian itu, pengajian tafsir al-Ibrīz juga merupakan salah satu bentuk dari suatu kegiatan pengajian. Yang mana didalam pengajian ini menjelaskan tentang isi tafsir al-Ibrizz itu sendiri oleh $\mathrm{KH}$. Mustofa Bisri. Para Jamaah pengajian tafsir al-Ibrizz yang beraneka ragam, baik dari segi usia maupun pekerjaan. Tetapi tetap saja semuanya mendapatkan ilmu dari sumber yang sama yaitu tafsir al-Ibrīz oleh KH Mustofa Bisri.

Bapak Zulkifli mengungkapkan bahwa selain menambah saudara, adanya pengajian ini memberikan wadah menimba ilmu dan wawasan ilmu agama yang tidak diragukan lagi. ${ }^{31}$ Ibu Fariqoh menambahkan bahwa penjelasan yang dipaparkan Gus Mus tidak membosankan. Bahkan keterangan yang ada tidak berpacu pada agama saja, melainkan melibatkan sains dan disiplin ilmu lain. ${ }^{32} \mathrm{Hal}$ senada dituturkan oleh Ibu Jati yang merupakan pensiunan pegawai negeri. ${ }^{33}$ Ia menggarisbawahi bahwa ketika di sekolah dulu diajarkan untuk saling menghormati dan menghargai, di sini pun Gus Mus sama tetapi dengan penyampaian yang berbeda dan lebih masuk ke dalam hati. Pak Suyoto salah satu jamaah pengajian dari Sulang megungkapkan: ${ }^{34}$

Keyakinan saya terhadap pengajian tafsir al-Ibrīz KH. Mustofa Bisri yaitu sebagai tempat untuk mendapatkan wawasan keilmuwan yang beraneka. Mulai dari keagamaan khususnya tentang isi dalam al-Quran yang mengajarkan banyak sekali pengetahuan. Selain itu, dari pengajian ini juga saya mendapatkan bagaimana sikap dalam menghadapi masyarakat, cara berdakwah, bagaimana Gus Mus menyampaikan hal-hal yang terkadang biasa menjadi lebih menarik sehingga para jamaah lebih bisa meresapi terhadap yang disampaikannya. Banyak sekali mbak ilmu yang saya dapat dari sini.

Dari pemaparan peserta jamaah pengajian tafsir al-Ibrīz diatas, selain keyakinan bahwa pengajian tafsir al-Ibrīz menjadi sumber berkah, sarana untuk mendekatkan diri kepada Allah Subhānahu wa Ta'ālā. Pengajian ini juga diyakini juga sebagai tempat untuk menambah banyak wawasan ilmu baik dari segi ilmu agama, bersosial masyarakat, bersikap

\footnotetext{
${ }^{30}$ Alfisyah, "Pengajian Dan Transformasi Sosiokultural Dalam Masyarakat Muslim Tradisionalis Banjar", Jurnal Dakwah dan Komunikasi, vol. 3, no. 1 (2009), hlm. 34.

${ }^{31}$ Wawancara dengan Zulkifli, Rembang, 13 April, 2018.

${ }^{32}$ Wawancara dengan Fariqoh, Rembang, 06 April, 2018.

${ }^{33}$ Wawancara dengan Jati, Rembang, 06 April, 2018.

${ }^{34}$ Wawancara dengan Suyoto, Rembang, 04 Mei, 2018.
} 
Pengajian Tafsir Al-Ibrīz Oleh Kiai Ahmad Mustofa Bisri .....

Mudawamah \& Muhamad Asif

Doi: doi.org/10.47454/itqan.v4i2.682

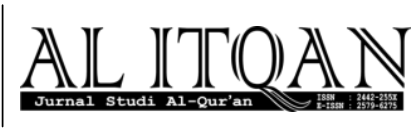

maupun bagaimana cara berdakwah yang dilihat dari sosok $\mathrm{KH}$ Mustofa Bisri ketka menyampaikan isi dalam Tafsir al-Ibrīz tersebut.

\section{d. Sarana Menyambung Tali Persaudaraan Sesama Muslim}

Menyambung tali persaudaraan sesama muslim merupakan hal yang tidak harus dengan saudara kandung, atau lingkup keluarga saja. Tetapi dengan semua orang, baik beragama Islam maupun Non Islam. Di Pengajian Tafsir al-Ibrīz KH. Mustofa Bisri ini diyakini juga sebagai sarana untuk menyambung tali persaudaraan sesama Muslim. Peserta jamaah yang beraneka ragam asalnya atau tempat tinggalnya berkumpul bersama dalam sebuah majelis pengajian tafsir al-Ibrizz setiap hari jumat. Sehingga yang awalnya tidak saling mengenal menjadi mengenal satu sama lain.

Keyakinan Jamaah Tafsir al-Ibrīz terhadap pengajian tafsir al-Ibrīz yang sebagai sarana menyambung tali persaudaraan terbukti dari beberapa uangkapan para jamaah yang penulis wawancarai. Diantaranya yaitu Ibu Fariqoh, Ibu Siti Masfufah, Ibu Zukhrotin, Bapak Rohman, Bapak Muhib. Ibu Fariqoh yang bertempat tinggal di Pati mengungkapkan bahwa adanya pengajian ini menambah saudara. Ia yang pertama kali tidak mengenal siapapun, sampai memiliki kenalan untuk menyambung tali persaudaraan sesama orang Islam. ${ }^{35}$ Begitu pun dengan Ibu Siti Masfufah ${ }^{\mathbf{3 6}}$, Ibu Zukhrotin ${ }^{37}$, Bapak Rohman ${ }^{38}$, dan Bapak Muhib ${ }^{39}$.

Dari pemaparan wawancara penulis dengan peserta jamaah pengajian tafsir al-Ibrīz menunjukkan bahwa salah satu keyakinan mereka tentang pengajian tafsir al-Ibrizz adalah sebagai sarana untuk bersilaturrahmi dan mempererat tali persaudaraan sesama umat Islam.

\section{e. Sarana Untuk Mengisi Waktu Luang}

Peserta Pengajian tafsir al-Ibrīz yang kebanyakan adalah orang tua dan juga merupakan orang yang sudah pensiun dari pekerjaannya. sehingga mereka tidak memiliki pekerjaan yang menetap dan banyak waktu luang yang mereka rasakan tidak bermanfaat. Yang awalnya ada kesibukan, setelah pensiunan mereka tidak mengerjakan apa-apa selain pekerjaan rumah tangga dan itu membuat mereka merasa jenuh. Karena merasa jenuh dan daripada menganggur mereka mengikuti pengajian tafsir al-Ibrīz KH Mustofa Bisri di Leteh.

\footnotetext{
${ }^{35}$ Wawancara dengan Fariqoh, Rembang, 13 April, 2018.

${ }^{36}$ Wawancara dengan Siti Masfufah, Rembang, 04 Mei, 2018.

${ }^{37}$ Wawancara dengan Zukhrotin, Rembang, 04 Mei, 2018.

${ }^{38}$ Wawancara dengan Rohman, Rembang, 27 April, 2018.

${ }^{39}$ Wawancara dengan Muhib, Rembang, 13 April, 2018.
} 
Ibu Jumini, yang berusia 67 tahun mengungkapkan bahwa pekerjaannya hanya sebagai ibu rumah tangga membuatnya menambah kegiatan dengan mengikuti pengajian tafsir ini agar hidupnya tidak terasa bosan. ${ }^{40}$ Hal senada diungkapkan ibu Kartini bahwa ia diajak tetangga rumah untuk ikut pengajian ini. Setidaknya waktu yang terbuang menjadi bermanfaat. ${ }^{41}$ Beda lagi dengan Ibu Sri Handani yang merupakan pensiunan dari Dinas Perikanan. ${ }^{\mathbf{4 2}}$ Ia mengatakan bahwa selepas pensiun, ia menganggur dan fikiran menjadi bosan. Biasanya satu minggu penuh bekerja, kini tidak melakukan apapun membuatnya berinisiatif mengikuti pengajian ini.

Selain ibu Jumini, Ibu Kartini dan Ibu Sri Handayani, ada 3 peserta pengajian yang penulis wawancarai yaitu; Ibu Rohmah, Ibu Munawwaroh dan Ibu Sukini yang memanfaatkan waktu luangnya dengan sering mengikuti pengajian tafsir al-Ibrīz sehingga tidak terlalu banyak menganggur di rumah.

\section{f. Sarana Untuk Mencari Rizki}

Pengajian tafsir al-Ibrīz dimulai sekitar tahun 1967 ini sudah mengalami perubahan. Perubahan dari siis pengampu pengajian maupun para peserta pengajian serta keadaan sekarang yang terlihat ketika pengajian berlangsung. Yang awalnya disampaikan oleh KH. Bisri Mustofa kemudan sekarang digantikan oleh putranya yaitu KH. Ahmad Mustofa Bisri. Selain itu, peserta yang semakin bertambah banyak serta para pedagang yang terlihat beraktifitas di area pengajian tafsir al-Ibrīz. di area jalanan tepatnya di depan kediaman Gus Mus mereka melakukan aktifitas jual beli, terkadang ada juga yang masuk dalam kumpulan para jammah. Ada pedagang es dawet, sayuran, jajanan pasar, baju dan minyak wangi. Para pedagang ini dulu belum ada, mereka mulai ada sekitar 5 tahun terakhir ini. ${ }^{43}$

Dari terlihatnya banyaknya pedagang, keyakinan para jamaah terhadap pengajian tafsir al-Ibrīz ada yang meyakini bahwa selain sebagai tempat mengaji tafsir tetapi juga sebagai tempat untuk mencari rizki. Hal ini diungkapkan oleh beberapa jamaah pengajian tafsir al-Ibrīz diantara yaitu Ibu Zulaihah yang merupakan pedagang baju mengungkapkan bahwa mengikuti pengajian tersebut tidah hanya sebagai ladang ilmu, melainkan juga ladang rizki baginya. Ia memaparkan bahwa meski dagangan yang dibawa kredit,setidaknya ada

\footnotetext{
${ }^{40}$ Wawancara dengan Jumini, Rembang, 04 Mei, 2018.

${ }^{41}$ Wawancara dengan Kartini, Rembang, 04 Mei, 2018.

${ }^{42}$ Wawancara dengan Sri Handani, Rembang, 27 April, 2018.

${ }^{43}$ Wawancara dengan Almas, Rembang, 09 September, 2018.
} 


\section{Pengajian Tafsir Al-Ibrīz Oleh Kiai Ahmad Mustofa Bisri ..... \\ Mudawamah \& Muhamad Asif \\ Doi: doi.org/10.47454/itqan.v4i2.682}

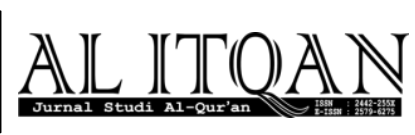

beberapa yang laku. ${ }^{44}$ Sedangkan Ibu Rohmah seorang pedangan jajanan pasar mengungkapkan bahwa banyak kebaikan yang ia dapat dalam pengajian tersebut. ${ }^{45}$ Selain pengajian sebagai tempat mendapatkan pengatahuan agama juga mendapatkan rizki baginya. Pekerjaannya sebagai pedagang, selain mengaji juga membawa dagangan untuk dijual. Hasilnya selalu habis ketika pulang ke rumah.

Selain ibu Rohmah ada juga Bapak Ahmad yang merupakan pedagang minyak wangi juga mengungkapkan bahwa ibarat peribahasa, sekali dayung dua pulai terlampaui. ${ }^{46}$ Ia mendapatkan ilmunya, jualan minyak juga laris. Keyakinan yang sama juga diungkapkan oleh Bapak Darmuji yang merupakan penjual es dawet, ia mengatakan: ${ }^{47}$

Saya hanya penjual es dawet saja, Mbak. Jadi saya tidak begitu mengerti tentang ilmu agama. Tapi menurut saya dipengajian Gus Mus ini saya begitu senang, selain saya tetap bisa bekerja saya setidaknya mendengarkan tentang ilmu agama disini. Biasanya saya melayani para pembeli disini, itu sebelum dan sesudah pengajian berlangsung. Jarang sekali pembeli ketika pengajian berlangsung mbak. Tapi alhamdulillah bapak tetep sering laris kalau disini. Jadi emnurut bapak pengajian tafsir al-Ibrīz ini ya bisa saja digunkan untuk tempat mencari rizki.

Dari penuturan para jamah tafsir al-Ibrizz di atas, keyakinan para peserta terhadap pengajian tafsir al-ibrīz yaitu sebagai salah satu tempat untuk mencari rizki.

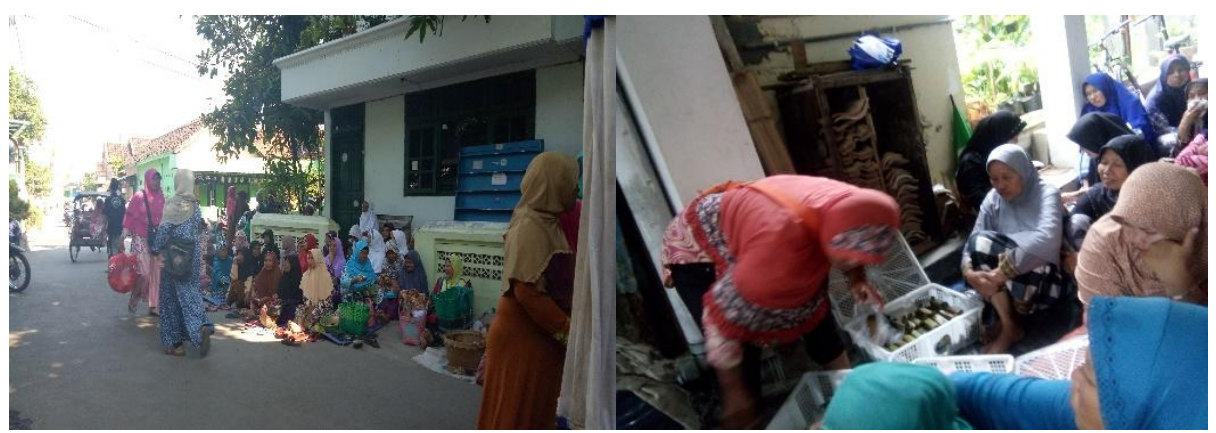

Gambar 15:

Aktifitas para pedagang di pengajian tafsir al-Ibrīz yang berada di depan kediaman Gus Mus sebelum dimulai pengajian tafsir al-Ibrizz oleh Gus Mus.
Gambar 16:

Ibu Rohmah yang merupakan salah satu pedagang jajanan pasar di pengajian tafsir al-Ibrīz sedang berjualan di tengah-tengah jamaah tafsir berada di garasi Gus Adib sebelum pengajian tafsir dimulai.

\footnotetext{
${ }^{44}$ Wawancara dengan Zulaihah, Rembang, 13 April, 2018.

${ }^{45}$ Wawancara dengan Rohmah, Rembang, 27 April, 2018.

${ }^{46}$ Wawancara dengan Ahmad, Rembang, 13 April, 2018.

${ }^{47}$ Wawancara dengan Darmuji, Rembang, 27 April, 2018.
} 


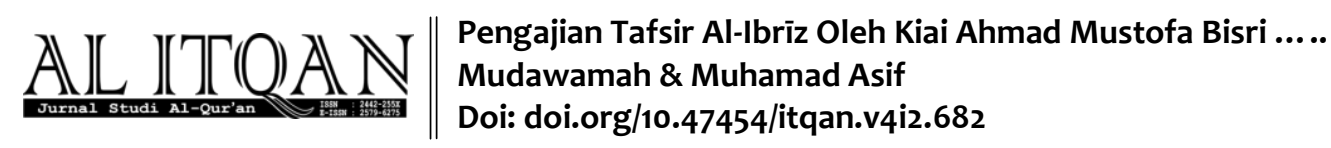

\section{g. Doa Khataman untuk mendapatkan hajat-hajat yang diinginkan.}

Pada hari jumat tanggal 11 Mei 2018, tafsir al-Ibrīz dikhatamkan. Hal ini merupakan acara yang sangat langka sekali, mengingat khataman ini berlangsung setelah 17 tahun tafsir al-Ibrīz dikaji oleh KH Ahmad Mustofa Bisri di pengajian tafsir al-Ibrīz di Pondok Pesantren Raudlatut Thalibin.

Banyak sekali jamaah yang hadir, ribuan orang hadir baik dari berbagai daerah dan kalangan, mulai pejabat hingga masyarakat biasa, memadati halaman pesantren. Dalam acara ini banyak hadir para pengasih pesantren dan pengampu pengajian tafsir al-Ibrīz, KH Ahmah Mustofa Bisri serta para kiai sekitar. yaitu Yahya Cholil Tsaquf, kiai Makin Shoimuri, Kiai Syarofuddin, Kiai Chazim Mabrur, Kiai Chatib Mabrur dan Kiai Najib. Selain itu, bapak Kapolres Rembang AKBP Pungky Bhuana Santoso juga menghadiri acara tersebut. Para kiai berdoa silih berganti dan ditutup oleh KH Ahmad Mustofa Bisri.

Jamaah yang datang membludak ini, diluar estimasi pihak panitia. panitia memperkirakan 3000 jamaah yang akan datang, ternyata lebih. ${ }^{48}$ Hal ini dapat dilihat dari masih kurangnya bingkisan yang disiapkan oleh pihak panitia dan ndalem pondok. Para jamaah yang hadir mendapatkan bingkisan yang berisi nasi dan buku kenang-kenangan khataman tafsir al-Ibrīz yang ditulis oleh KH Ahmad Mustofa Bisri yang berisi tentang keutamaan dan adab membaca al-Quran serta sejumlah amalan. Jamaah juga mendapatkan air yang disediakan panitia.Seperti halnya yang diungkapkan oleh ibu Sri Handani, jamaah yang hadir dalam khataman tafsir al-Ibrīz bahwa rasa syukur ia ungkapkan dengan membawa air botol sebagai bentuk meminta barokah doa khataman. Hal ini bertujuan nantinya dapat berkah khataman tidak hanya ia rasakan saja, melainkan bersama keluarga besar di rumah. ${ }^{49}$ Semisal, keluarga yang mulanya sakit menjadi sembuh, yang awalnya kurang baik menjadi baik dan lain lain yang penting yang baik-baik.Bapak Adib juga mengungkapkan: ${ }^{50}$

Dengan menghadiri khataman tafsir al-Ibrīz ini, banyak sekali manfaatnya mbak. barokah yang didapatkan juga banyak. Karena disini tempat berkumpulnya orang-orang baik insyallah, para kiai juga sehingga doadoa serta hajat-hajat yang kita inginkan insyallah akan mudah didengar oleh Allah Subhānahu wa Ta'ālā. Khataman tafsir al-Ibrīz juga sangat langka sekali kita bisa menemui kan mbak, hal ini saja sampai 17 tahun kita mengaji baru bisa menghatamkannya.

\footnotetext{
${ }^{48}$ Wawancara dengan Suyoto Zuhdi, Rembang, 11 Mei, 2018.

${ }^{49}$ Wawancara dengan Sri Handani, Rembang, 11 Mei, 2018.

${ }^{50}$ Wawancara dengan Adib, Rembang, 11 Mei, 2018.
} 
Pengajian Tafsir Al-Ibrīz Oleh Kiai Ahmad Mustofa Bisri ..... Mudawamah \& Muhamad Asif

Doi: doi.org/10.47454/itqan.v4i2.682

Selain itu bapak Abdurrohman mengungkapkan: ${ }^{51}$

Saya berharap dengan menghadiri khataman ini kita mendapatkan barokah dari tafsir al-Ibrīz itu sendiri serta dari doa-doa para kiai. Air yang saya bawa ini untuk keluarga saya yang dirumah semoga sehat dan selalu dalam perlindungan Gusti Allah Subhānahu wa Ta'ālā, semkain bertambah ibadahnya.

Para jamaah yang hadir meyakini dengan mengikuti khataman tafsir al-Ibrīz doa-doa serta hajat-hajat mereka akan mudah terkabul. Mereka yakin bahwa dengan diaminkan oleh banyak orang serta para kiai doa-doa tersebut akan mudah didengarkan oleh Allah Subhānahu wa Ta'ālā.

\section{E. Internalisasi Nilai-Nilai Agama yang Terkandung dalam Pengajian Tafsir Al-Ibrīz Oleh KH. Ahmad Mustofa Bisri}

Internalisasi adalah penghayatan terhadap suatu ajaran, doktrin, atau nilai sehingga merupakan keyakinan dan kesadaran akan kebenaran doktrin atau nilai yang diwujudkan dalam sikap dan perilaku. ${ }^{52}$ Sedangkan nilai agama adalah konep mengenai penghargaan tinggi yang diberikan oleh warga masyarakat pada beberapa masalah pokok dalam kehidupan keagamaan yang bersifat suci sehingga menjadikan pedoman bagi tigkah laku keagamaan warga masyarakat bersangkutan. Sehingga Internalisasi nilai-nilai agama yaitu proses menghayati serta memasukkan nilai-nilai agama yang terkandung dalam pengajian tafsir alIbrīz di Pondok Pesantren Raudlatut Thalibin ke dalam sikap atau tingkah laku para jamaah pengajia tafsir al-Ibrīz.

Berdasarkan observasi dan wawancara dari beberapa jamaah pengajian tafsir al-Ibrīz mengenai proses internalisasi nilai-nilai agama yang terkandung dalam pengajian tafsir alIbrīz dapat disimpulkan bahwa proses internalisasi para jamaah sebagai berikut:

1. Mendengarkan seksama penjelasan dari $\mathrm{KH}$ Ahmad Mustofa Bisri ketika menerangkan tafsir al-Ibrīz.

Awal dari internalisasi nilai-nilai agama para jamaah tafsir al-Ibrīz di Pondok Pesantren Raudlatut Thalibin yaitu dengan mendengarkan dengan seksama penjelasan yang

\footnotetext{
${ }^{51}$ Wawancara dengan Abdurrohman, Rembang, 11 Mei, 2018.

${ }^{52}$ Pusat Bahasa Departemen Pendidikan Nasional, Kamus Bahasa Indonesia (Jakarta: Pusat Bahasa, 2008), hlm. 376.
} 
disampaikan oleh KH Ahmad Mustofa Bisri. Hal ini diungkapkan oleh Ibu Fariqoh yang merupakan salah satu jamaah pengajian tafsir al-Ibrīz, ia mengungkapkan: ${ }^{53}$

Dalam proses internalisasi nilai-nilai agama yang terkandung dalam pengajian tafsir al-Ibrīz menurut saya ya dengan mendengarkan seksama penjelasan Kiai Mus mbak, setelah itu kemudian dengan mengkaji ulang tafsir al-Ibrīz ketika dirumah dengan cara dibaca sesering mungkin. Dengan cara mendengarkan dan membaca ulang nanti kita akan bisa penghayati nilai-nilai agama apa saja terkandung dalam tafsir al-Ibrīz tersebut. Setelah mengetahui apa saja nilai yang terkandung, kita kemudian mempraktekannya sebisa mungkin. Terkadang mbak kita tidak bisa mempraktekkan secara sepenuhnya tapi kita bisa mempraktekkan secara sederhana saja, contohnya sebisa mungkin meningkatkan ibadah kita, menambah sholat sunnah, sering berziarah ke makam waliyullah seperti itu mbak. ya sebisa mungkin kita biasakan dalam kehidupan kita. Kalau saya biasanya ya dengan memberi para pengemis mbak sebisa mungkin. Mungkin dnegan sodaqoh sedikit lama-lama bisa menjadi bisa sodaqoh banyak.

Selain ibu Fariqoh, Ibu Jati juga memaparkan ungkapan yang sama, yakni: ${ }^{54}$

Kalau saya pertama-pertama kita harus seksama dalam mendengarkan penjelasan Gus mus mbak. kerena mendengarkan tersebut kan kita akan tahu niali-nilai apa saja yang terkandung dalam tafsir al-Ibrīz tersebut. Soalnya belum tentu kita membacanya sendiri kita akan langsnug mengerti makna yang terkandungnya. Makanya ketika saya mengikuti pengajian ini ya saya dengan semampu saya dan saya usahakan untuk menyimak dan mendengarkan dengan seksama jangan sampai ada yang terlewati. Karena kita tidak memungkiri kalau terkadang ada-ada saja ibu-ibu yang saling mengobrol ketika Gus Mus menjelaskan. Biasanya saya sebisa mungkin masuk ke aula mbak, karena jika diluar aula menurut saya banyak suara-suara yang menganggu konsentrasi kita ketika lagi enak-enaknya mendengarkan penjelasan dari Gus Mus.

\section{Mengkaji Ulang Kitab Tafsir Al-Ibrīz Ketika diRumah.}

Tahap kedua dari internalisasi nilai-nilai agama yang terkandung adalam pengajian tafsir al-Ibrīz yaitu dengan cara mengkaji ulang kitab tafsir al-Ibrīz ketika dirumah. Mengkaji ulang ulang ini maksudnya dengan membaca disaat dirumah sebelum amupun sesudah pengajian tafsir al-Ibrizz pada hari jumat, ketika diwaktu senggang. Hal ini dilakukan oleh ibu Fariqoh, Pak Abdurrahman dan ibu jati dan Pak Suyoto. Ibu Jati mengungkapan bahwa selepas maghrib, ia sempatkan membaca ulang tafsir al-Ibrīz sambil mengingat-ingat kembali

\footnotetext{
${ }^{53}$ Wawancara dengan Fariqoh, Rembang, 06 April, 2018.

${ }^{54}$ Wawancara dengan Jati, Rembang, 05 Mei, 2018.
} 
Pengajian Tafsir Al-Ibrīz Oleh Kiai Ahmad Mustofa Bisri ..... Mudawamah \& Muhamad Asif

Doi: doi.org/10.47454/itqan.v4i2.682

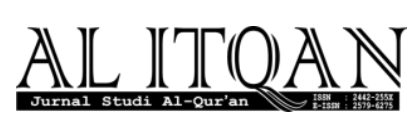

penjelasan dari Gus Mus ${ }^{55}$ Pak Abdurrahman juga mengulang lagi membaca tafsir tersebut. Ia menambahkan bahwa ketika mengaji saat itu dengan kondisi di mana ketika sedang membacanya sendiri di rumah,tiba-tiba saja kita ingat sesuatu hal harus diperbaiki dari diri sendiri. $^{56}$

\section{Menerapkan Nilai-Nilai Agama Secara Perlahan terhadap Diri Sendiri.}

Tahap yang ketiga yaitu dengan cara menerapkan nilai-nilai yang terkandung tersebut kedalam diri sendiri. Hal ini diungkapakan dnegan hal kecil saja yaitu menerapkan saling menyapa dengan orang ketika bertemu, membiasakan tetap tapt waktu ketika beribadah, sering-sering berziaroh kubur kemakam waliyullah. Seperti yang diungkapkan oleh ibu Fariqoh sebagai berikut: ${ }^{57}$

Saya menginternalisasikan nilai-nilai agama dari pengajian tafsir ini ya dengan mendengarkan penjelasan Gus Mus, kemudian membaca berulang-ulang dirumah, kemudian dari situ kita akan tau niali apa yang terkandung. Setelah tau niali yang terkandung saya menerapkan pada diri sendiri dulu mbak, secara perlahan saja, contohnya yaitu dengan tepat waktu dalam beribadah, saling menyapa dengan orang yang kita temui.

Hal serupa juga diungkapkan oleh Ibu Jati, ia mengungkapkan:

Saya biasa menrapkan kediri sendiri dulu mbak, seperti halnya tenlali dalam solat, nambah dalam berzikir, sering bersyukur dengan cara bershodaqoh. Pokoknya hal hal yang untuk diri kita sendiri kita harus terapkan mbak.

\section{Membiasakan Nilai-Nilai Agama yang Sudah Diterapkan dalam Kehidupan Sehari-}

hari.

Tahap terakhir dari internalisasi niali-nilai agam yang terkandung dalam pengajian tafsir al-Ibrīz yatu membiasakan dalam kehidupan sehari-hari. Contohnya saja dengan sering bersedekah, sedkah tidak harus dengan banyak harta bisa dengan memberi ke pengemis yang ada dijalanan. Sering berziaraj kemakam waliyullah yang terdekat di rumah masing-masing. Hal ini sesuai dengan yang diungkapkan oleh Pak suyoto, Ibu Fariqoh serta Ibu Jati. Ibu Jati juga mengungkapkan: ${ }^{58}$

Cara saya menginternalisasikan nilai-nilai agama dalam pengajian tafsir alIbrīz ya dengan sesering mungkin menghadiri pengajian ini, biar kita tahu nilai-nilai agama yang terkandung kemudian setelah itu sebisa mungkin saya praktikkan mbak. Ya dari yang kecil-kecil dulu mbak, mungkin dari diri

\footnotetext{
${ }^{55}$ Ibid.,

${ }^{56}$ Wawancara dengan Abdurrohman, Rembang, 11 Mei, 2018.

${ }^{57}$ Wawancara dengan Fariqoh, Rembang, 06 April, 2018.

${ }^{58}$ Wawancara dengan Jati, Rembang, 06 April, 2018.
} 


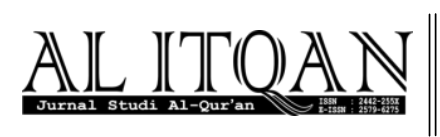

Pengajian Tafsir Al-Ibrīz Oleh Kiai Ahmad Mustofa Bisri .....

Mudawamah \& Muhamad Asif

Doi: doi.org/10.47454/itqan.v4i2.682

sendiri membenahinya untuk lebih baik contohnya tidak mudah berburuk sangka terhadap orang lain, tidak mudah iri, ya sebisa mungkin mengatur hati kita mbak. iya kita sering sering jangan merasa benar.

Bapak Suyoto juga mengungkapkan: ${ }^{59}$

Internalisasi nilai-nilai agama dalam pengajian tafsir al-Ibrīz ya dengan seksama mendengarkan penjelasan dari Gus Mus mbak, kemdian kita pikirpikir pada diri kita apa yang masih salah pada diri kita, apa yang belum kita lakukan. Ya bisa dikatakan kita butuh intropeksi diri kita sendiri sehingga kita tahu nantinya perbuatan-perbuatan apa saja yang kita harus benahi atau kalau tidak begitu perbuatan yang perlu ditambah kebaikannya. Dirumah juga kita harus juga membaca tafsir al-Ibrīz bukan hanya ketika hari jumat saja. Mengaji bukan hanya dipengajian selasa jumat saja juga bisa mbak. pokoknya sebisa mungkin mempraktekkan niali-nilai agama yang terkandung dalam pengajian tafsir al-Ibrizz yang dterangkan oleh Gus Mus mbak. Contohnya saja dengan sodaqoh, berziarah ke makam waliyullah, dan masih banyak lagi mbak. yang penting itu kita mendengarkan, menelaah, mempraktekkan serta membiasakannya dalam kehidupan sehari-hari mbak.

\section{F. Kesimpulan}

Berdasarkan pemaparan hasil penelitian tentang keyakinan para jamaah tafsir al-Ibrīz dan internalisasi nilai-nilai agama para jamaah dalam pengajian tafsir al-Ibrīz di Pondok Pesantren Raudlatut Thalibin oleh KH Ahmad Mustofa Bisri, dapat ditarik kesimpulan sebagai berikut; Pertama Pengajian tafsir al-Ibrīz dilaksanakan setiap seminggu sekali pada hari jumat dimulai pukul 08.00 atau 08.30 dan berlangsung selama satu jam di Pondok Pesantren Raudlatut Thalibin Rembang. Diampu oleh Kiai Ahmad Mustofa Bisri yang mana terkadang dibadali oleh Kiai Syarofuddin. Peserta pengajian berjumalah kurang lebih 1000 orang yang mana terdiri dari orang tua, anak muda, pedagang, pensiunan. Pengajian diawali dengan salam dari Gus Mus, al-fatihah kemudian membaca ayat yang akan disampaikan serta diakhiri dengan bacaan waallah 'alam bișsawāb, hamdalah dan al-fatihah. Para jamaah mendengarkan dengan khusyuk dan setiap Gus Mus selesai membaca satu ayat al-Quran mereka menjawab dengan kata Allah. Tradisi dalam pengajian ini yaitu setiap peserta datang maupun akan pulang pengajian, mereka saling bersalaman, dan tidak lupa juga berebut salam dengan Gus Mus ketika beliau lewat. Pada hari jumat wage jumlah peserta semakin banyak karena pada hari itu dari pihak ndalem memberikan shodaqah makan kepada para jamaah, selain itu banyaknya para pedagang yang ada di area pengajian yang mana pedagang juga mengikuti pengajian tafsir tersebut.

\footnotetext{
${ }^{59}$ Wawancara dengan Suyoto Zuhdi, Rembang, 29 April, 2018.
} 
Pengajian Tafsir Al-Ibrīz Oleh Kiai Ahmad Mustofa Bisri ..... Mudawamah \& Muhamad Asif

Doi: doi.org/10.47454/itqan.v4i2.682

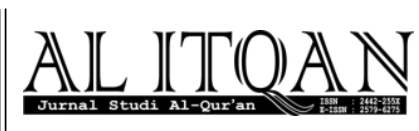

Kedua,Keyakinan parajamaah Pengajian Tafsir al-Ibrīz terhadap Pengajian Tafsir alIbrīz KH. Mustofa Bisri di Pondok Pesantren Raudlatut Thalibin terdapat 7 bentuk keyakinan, yaitu Menjadikan sebagai ladang berkah, sarana untuk lebih dekat dengan Allah Subhānahu wa Ta'ālā, sarana untuk menambah wawasan keilmuwan, sarana menyambung tali persaudaraan sesama muslim, sarana mengisi waktu luang, sarana untuk mencari rizki, dan menjadikan doa khataman untuk mendapatkan hajat-hajat yang diinginkan.

Ketiga,carapara jamaah Pengajian Tafsir al-Ibrīz dalam menginternalisasikan nilainilai agama yang terkandung dalam Pengajian Tafsir al-Ibrīz oleh KH. Mustofa Bisri di Pondok Pesantren Raudlatut Thalibin yaitu mendengarkan dengan seksama penjelasan dari KH Ahmad Mustofa Bisri ketika menerangkan tafsir al-Ibrīz,mengkaji ulang kitab tafsir alIbrīz ketika dirumah, menerapkan nilai-nilai agama secara perlahan terhadap diri sendiri., serta membiasakan nilai-nilai agama yang sudah diterapkan dalam kehidupan sehari-hari. 


\section{DAFTAR PUSTAKA}

Ahimsa, Heddy Sri. "Fenomenologi Agama: Pendekatan Fenomenologi untuk Memahami Agama" Jurnal Walisongo. vol. 20. no. 2. (http://dx.doi.org/10.21580/ws.20.2.200).

Alfisyah."Pengajian Dan Transformasi Sosiokultural Dalam Masyarakat Muslim Tradisionalis Banjar”. Jurnal Dakwah dan Komunikasi. vol.3, no. 1 (2009).

Bisri, Mustofa. "Dialog dalam Acara Penerimaan Peserta PKL". Rembang, 28 September, 2017.

Dhofir, Zamakhsyari. Tradisi Pesantren Studi Pandangan Hidup Kyai dan Visinya Mengenai Masa Depan Indonesia. Jakarta: LP3ES, 2011.

Dzalieq, Ahmad Bisri. “KH. Bisri Mustofa dan Perjuangannya”. Skripsi, Yogyakarta: UIN Sunan Kalijaga, 2008.

Hasbiansyah, O. “ Pendekatan Fenomenologi: Pengantar Praktik Penelitian dalam Ilmu Sosial dan Komunikasi” Mediator Jurnal Komunikasi. vol. 9, no. 1 (2008) (https://doi.org/10.29313/mediator.v9i1.1146).

Huda, Achmad Zainal. Mutiara Pesantren Perjalanan Khidmah KH. Bisri Mustofa. Yogyakarta: Pustaka Pesantren, 2005.

Mansur, M. "Living Qur'an dalam Lintasan Sejarah Studi Qur'an”, dalam Metodologi Penelitian Living Qur'an dan Hadis. Ed. Sahiron Syamsuddin. Yogyakarta: TH Press, 2007.

Mimbar Bebas dan Alumni 1425 Madrasah Robin. Para Pejuang Dari Rembang. Rembang: Mata air Syndicate, 2006.

Mulyana, Deddy. Metodologi penelitian Kualitatif, Paradigma Baru Ilmu Komunikasi dan Ilmu Sosial lainnya. Bandung: remaja Rosdakarya, 2001.

Mustaqim, Abdul. Metode Penelitian al-Quran dan Tafsir. Yogyakarta: Idea Press, 2015.

Mustofa, Bisri. al-Ibrīz Li Ma'rifah Tafsīr al-Qur'an al-Azìz. Kudus: Menara Kudus, t.th.

Pusat Bahasa Departemen Pendidikan Nasional. Kamus Bahasa Indonesia. Jakarta: Pusat Bahasa, 2008. 
Pengajian Tafsir Al-Ibrīz Oleh Kiai Ahmad Mustofa Bisri ..... Mudawamah \& Muhamad Asif

Doi: doi.org/10.47454/itqan.v4i2.682

\section{Wawancara}

Wawancara dengan Abdurrohman, Rembang, 11 Mei, 2018.

Wawancara dengan Adib Bisri Hattani, Rembang, 29September, 2017.

Wawancara dengan Adib Bisri Hattani, Rembang, 20 April, 2018.

Wawancara dengan Adib Bisri Hattani, Rembang, 11 Mei, 2018.

Wawancara dengan Ahmad Mustofa Bisri, Rembang, 29 September, 2017.

Wawancara dengan Ahmad Mustofa Bisri, Rembang, 13 April, 2018.

Wawancara dengan Ahmad Mustofa Bisri, Rembang, 24 Agustus, 2018.

Wawancara dengan Ahmad Mustofa Bisri, Rembang, 09 September, 2018.

Wawancara dengan Almas, Rembang, 24 Agustus, 2018.

Wawancara dengan Darmuji, Rembang, 27 April, 2018.

Wawancara dengan Fariqoh, Rembang, 06 April, 2018.

Wawancara dengan Jati, Rembang, 05 Mei, 2018.

Wawancara dengan Jati, Rembang, 06 April, 2018.

Wawancara dengan Jumini, Rembang, 04 Mei, 2018.

Wawancara dengan Kartini, Rembang, 04 Mei, 2018.

Wawancara dengan Kasini, Rembang, 29 April, 2018.

Wawancara dengan Khodijah, Rembang, 06 April, 2018.

Wawancara dengan Khomariyah, Rembang, 06 April, 2018.

Wawancara dengan Lu'lu' Khotimah, Rembang,13 April, 2018.

Wawancara dengan Makin Shoimury, Rembang, 29 September, 2017.

Wawancara dengan Mariatun, Rembang, 29 April, 2018.

Wawancara dengan Muhib, Rembang, 13 April, 2018.

Wawancara dengan Rohmah, Rembang, 27 April, 2018.

Wawancara dengan Sarman, Rembang, 06 April, 2018. 


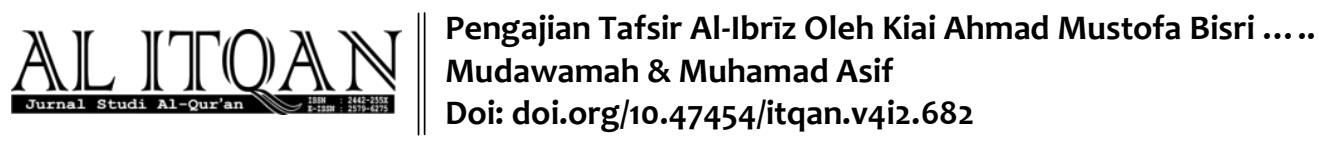

Wawancara dengan Shafawi, Rembang, 06 April, 2018.

Wawancara dengan Siti Masfufah, Rembang, 04 Mei, 2018.

Wawancara dengan Sri Handani, Rembang, 11 Mei, 2018.

Wawancara dengan Sri Handani, Rembang, 27 April, 2018.

Wawancara dengan Suyoto Zuhdi, Rembang, 13 April, 2018.

Wawancara dengan Suyoto Zuhdi, Rembang, 29 April, 2018.

Wawancara dengan Suyoto Zuhdi, Rembang, 04 Mei, 2018.

Wawancara dengan Suyoto Zuhdi, Rembang, 11 Mei, 2018.

Wawancara dengan Syarofuddin, Rembang, 29 September, 2017.

Wawancara dengan Zainuddin, Rembang, 29 September, 2017.

Wawancara dengan Zukhrotin, Rembang, 04 Mei, 2018.

Wawancara dengan Zulaihah, Rembang, 13 April, 2018.

Wawancara dengan Zulkifli, Rembang, 13 April, 2018. 